\title{
La comunidad de los hombres solos: Mónica Sanders de Salvador Reyes ${ }^{1}$
}

The community of men alone: Mónica Sanders by Salvador Reyes

\author{
Felipe André González Alfonso \\ Pontificia Universidad Católica de Valparaíso \\ Universidad de Playa Ancha \\ felipe.gonzalez.a@pucv.cl
}

\section{Resumen}

La novela Mónica Sanders (1951) de Salvador Reyes (1889-1970) tiene como subtexto histórico, por una parte, la decadencia económica del Valparaíso posterior al Crac de 1929 y, por otra, la pujante industria ballenera de Quintay durante los años cuarenta del mismo siglo. Mediante el enlazamiento conceptual de espacio, imaginarios y comunidad, este trabajo destaca una serie de oposiciones y ambivalencias que configuran la estructura ideológica del texto. Mientras en el espacio citadino predomina la comunidad inglesa representada bajo un imaginario decadente y encarnada en el personaje femenino de Mónica Sanders; en el espacio marítimo se despliega una comunidad nórdica bajo un imaginario de vitalidad masculina, afín al tópico vanguardista del "hacerse salvajes". Se va trazando así un mapa territorial-valorativo, con implicancias de género y nacionalidad, de los distintos sectores y sujetos de Valparaíso, y al menos dos formas de pensar la comunidad.

Palabras clave: Salvador Reyes, Mónica Sanders, Valparaíso, espacio, comunidad.

\begin{abstract}
The novel Mónica Sanders (1951) by Salvador Reyes (1889-1970) has, as a historical subtext, on the one hand, the Valparaíso's economic decline after Wall Street Crash in 1929; and, on the other hand, the strong Quintay's whaling industry during 1940s. Through the concepts of space, imaginaries and community, the current research highlights a series of oppositions and ambivalences that shape the ideological structure
\end{abstract}

1 Este escrito se desprende de la ponencia "Hacerse salvajes: espacios, imaginarios y comunidades en Mónica Sanders de Salvador Reyes", presentada en el XXII Congreso Internacional de la Sociedad Chilena de Estudios Literarios SOCHEL. Cartografías e imaginarios de la literatura chilena reciente: espacios, temporalidades y sujetos. Aniversario 40 años, realizado el mes de octubre de 2019 en el campus San Joaquín de la Pontificia Universidad Católica de Chile. 
of the novel. The English community prevails in the city space, represented by means of a decadent imaginary and embodied in the female character of Mónica Sanders. Whereas, in the maritime space, a Nordic community grows under an imaginary of masculine vitality, related to the avant-garde topic of "become wild". So, a territorial-evaluative map is being drawn up (with its implications on gender and nationality) of the different sectors and subjects of Valparaíso, and at least two ways of thinking about the community.

Keywords: Salvador Reyes, Mónica Sanders, Valparaíso, space, community.

Recibido: $12 / 04 / 2020$

Aceptado: 02/03/2021

\section{Introducción}

Mónica Sanders (1951) es la quinta novela de largo aliento publicada por Salvador Reyes, Premio Nacional de Literatura, y a la fecha ocupa un lugar respetable en nuestra historiografía literaria, por el que puede considerársela plenamente integrada al canon de la novelística nacional y, por supuesto, al más difuso canon de la literatura de Valparaíso. ${ }^{2}$ Aunque no por esto ha tenido una amplia recepción crítica ni lecturas que profundicen en su vínculo porteño. Vistos desde el interés de este trabajo, los escasos acercamientos que se registran — varios de ellos sólo circunstanciales notas de prensa-, se han centrado principalmente en el ambiente marítimo, en el marinismo general de Salvador Reyes, o bien en el espesor metafísico-filosófico de la novela, con énfasis en el mar y lo masculino. ${ }^{3} \mathrm{Y}$ han evitado, como se pretende aquí, indagar la especificidad del espacio porteño representado, y su relación con la historia, con las comunidades e imaginarios de la ciudad. ${ }^{4}$ De

2 Se ubica, según la periodización de Goic, en la primera generación del período superrealista, la de 1927 (75).

3 El "Prólogo" de Luis Oyarzún a la primera edición de 1951 es paradigmático de esta aproximación metafísica, que diluye la significación histórica de los elementos novelísticos, tratados en tanto arquetipos: "Mónica Sanders — y ya se advertía algo de lo mismo en obras ulteriores de Reyes - es la versión de un duelo entre el hombre y la existencia, que Salvador Reyes traduce con su lirismo sin esperanza" (11).

4 En la sección reservada para Salvador Reyes en su Historia de la literatura chilena (1956), Hugo Montes y Julio Orlandi enfatizan, sobre todo, el interés marítimo de la literatura de Reyes. Por su parte, en el artículo de Ana Ramírez, "Valparaíso en la perspectiva literaria del imaginismo" (1980), de gran interés en su enfoque, la novela aparece como un texto central del marinismo de Reyes, y también ahí se da predominancia al entorno marítimo, lo cual, en todo caso, sólo es exacto para el comienzo de la novela: "La proyección oceánica de Valparaíso está dada en la novela de Salvador Reyes, Mónica Sanders, donde la caza de la ballena nos aleja del ambiente porteño para enfrentarnos a la furia del mar y de sus criaturas" (115). En general, Ana Ramírez va a la búsqueda de tópicos y arquetipos de orden "universal” para hacer 
todos modos, es justo constatar que desde un inicio se señala la importancia e incluso el protagonismo de Valparaíso en Mónica Sanders y, siguiendo esta línea, algunos trabajos recientes orientan su análisis a partir de los rasgos propios del espacio elaborado en su doble dimensión portuaria y citadina.

Comenzando por la crítica más cercana a la publicación de la novela, ya en 1951 Alone se percata de la importancia de la espacialidad y señala en su confección un "preciso realismo de la indicación exacta, geográfica, urbana", y en consecuencia apunta que la ciudad "podría considerarse en la novela tan personaje como Julio Moreno y su buque, o la bella y poderosa Mónica Sanders” (243). En 1975, el crítico porteño Hernán del Solar hace también un breve, aunque iluminador deslinde, considerando la representación femenina y del entorno: “A pesar de que Mónica le da su nombre a la novela, que ante todo es una visión del puerto de Valparaíso nocturno, poblado de aventureros, borrachos, prostitutas, la verdad es que la mujer tiene por estas páginas un tránsito fugaz" (s/p). Como Alone, Hernán del Solar deja constancia del persistente interés del narrador por describir con minucia el trazado urbano y la geografía de la ciudad, y así aclara que estos no figuran como un simple telón de fondo. Vale también señalar un punto reiterativo en distintos comentarios, y es una supuesta incongruencia en el hecho de que Reyes titule su novela con el nombre de un personaje al parecer secundario o que no posee el rol protagónico de Julio Moreno. Esto es cuestionado en dos artículos que, al mismo tiempo, resaltan el papel provocador y activo del personaje de Mónica Sanders e insisten en la relevancia del espacio porteño en la elaboración textual.

El primer artículo, "Porteñas buenas mozas: corazón y belleza en la construcción de la mujer en la narrativa de Salvador Reyes" (2016), de Candia-Rosales-Landaeta, hace visible el estrecho vínculo entre la representación espacial y la representación femenina. Refiriéndose en general a las novelas del autor ambientadas en Valparaíso, señalan, por ejemplo, que "escribe textos donde no sólo reconstruye el 'imaginario urbano' del puerto, asumiendo una clara vocación 'anárquica' en la representación del espacio, sino que crea, además, personajes femeninos que desempeñan roles centrales en el desarrollo de los mismos" (158). En el segundo artículo, "Pleamar del deseo en la narrativa de Salvador Reyes" (2017), Candia-Rosales ven en el mar y su entorno portuario uno de los cinco elementos estructurantes de la narrativa de Reyes. Ya no es arquetipo de la muerte o lo desconocido, sino elemento situado, parte de la historia y las comunidades de Valparaíso,

de Reyes un Conrad o un Melvin chileno. Con un tenor similar, Manuel Montecinos rememora la obra de "Reyes, el gran marinista" (1994), elogiando "las hermosas descripciones de sectores de Valparaíso, particularmente aquellos que guardan un sabor típico” (7). 
"constitutivo de la identidad porteña no sólo por la serie de actividades económicas y de esparcimiento asociadas al Océano Pacífico, sino como un elemento que convierte a la ciudad en una puerta de entrada y salida al resto del mundo" (64). Enfatizan también el estrecho y coherente vínculo entre la representación de Valparaíso y los personajes femeninos en la narrativa porteña de Reyes, pues la mujer se encuentra, dice, "inserta en una ciudad, Valparaíso, profundamente liberal, abierta y cosmopolita” (78).

A pesar de no ser copiosa, la recepción crítica de Mónica Sanders ha transitado, como se ve, desde una mirada marinista y metafísica, hacia otra que, desarrollando los comentarios aislados de la crítica anterior, comienza a reconocer el significado específico del espacio, los imaginarios y las comunidades de la ciudad-puerto, y en relación con su historia cosmopolita de auge y decadencia económica. La aproximación de este trabajo, de hecho, ofrece una lectura vinculada al subtexto histórico de la novela: por una parte, la decadencia económica del Valparaíso posterior al Crac de 1929 y, por otra, la pujante industria ballenera de Quintay durante los años cuarenta del mismo siglo. Mediante el cruce de la triada conceptual de espacio, imaginarios y comunidad, quiero apreciar una serie de oposiciones y ambivalencias que develan la estructura ideológica del texto. Mientras en el espacio urbano se conforma una comunidad asfixiante, vinculada a la ya alicaída inmigración inglesa encarnada en el personaje femenino de Mónica Sanders; en el mar se despliega una comunidad nórdica (noruegos, finlandeses) que en el imaginario novelístico porta una vitalidad masculina afín al tópico vanguardista del "hacerse salvajes". Se observa así un mapeo territorial-valorativo de los distintos sectores y sujetos de Valparaíso (con implicancias de género y ascendencia), así como dos formas contrapuestas de pensar la comunidad en el espacio porteño.

\section{Espacio e imaginarios: el embrujo del capital}

En la crónica de los años setenta “¿Existe el embrujo de Valparaíso?”, Salvador Reyes acusa la pérdida de una emoción propia de la ciudad al dejar esta de recibir masivamente los acostumbrados barcos de pasajeros. Dice Reyes que "[c] uando antes de las líneas aéreas Valparaíso era la plataforma giratoria del viaje internacional tenía, naturalmente, una emotividad muchísimo mayor que la de hoy", y se lamenta porque ya "nadie paladea la 'amarga voluptuosidad' de ver cómo la costa queda atrás en la estela del navío" (Crónicas 148). Me parece este un punto de vista iluminador para el análisis de su novela Mónica Sanders, pues vincula las transformaciones espaciales llevadas a cabo por el capital con las variaciones afectivas respecto al entorno urbano, que desplazan y renuevan los imaginarios sociales. Reconstruyendo la teoría geográfica de Marx sintetizada en la fórmula de "la 
aniquilación del espacio por el tiempo”, el geógrafo David Harvey ha demostrado en detalle cómo las transformaciones espaciales operadas por las necesidades del capital —ya que el aumento del plusvalor exige la reducción de distancias-, transforman también la temporalidad social y, por consiguiente, las formas de vida en comunidad (262-263). El sistema capitalista altera el espacio mediante un proceso de crisis periódicas, dependiente de tres elementos: excedente de mano de obra para la reinversión expansiva del capital; disponibilidad de medios de producción; mercados consumidores para las nuevas mercancías (Harvey 256-257). Salvador Reyes captó con destreza narrativa y simbólica la aplicación radical de este proceso en Valparaíso: vibrante etreport del Pacífico en la segunda mitad del siglo XIX y luego, andando el siglo XX, por una serie de circunstancias históricas en que su devaluación como infraestructura estratégica de flujo mercantil no es la menor, ciudad en lento pero constante desmedro económico. Mónica Sanders, como se verá, reelabora este espacio-tiempo incorporando diversas influencias literarias, principalmente de tema marítimo, así como algunos imaginarios sociales de Valparaíso disponibles en la época, ya sea poniéndolos en tensión o renovándolos.

En su abarcador análisis de los imaginarios urbanos en la narrativa latinoamericana, Lucía Guerra entiende el concepto como un conjunto de "[i]mágenes y representaciones simbólicas que se nutren tanto de un imaginario social y mediático como de las imágenes y significados que [el sujeto como ser social] le infunde desde sus propias experiencias" (17). Recalco la variedad de fuentes señaladas por Lucía Guerra; los imaginarios sociales entrelazan: 1) imágenes colectivas, 2) imágenes mediáticas o culturales e 3) imágenes empíricas individuales (las del escritor en el caso de la novela). En el estudio de los imaginarios urbanos, esto tiene varias implicancias: las imágenes influyen en las construcciones identitarias, en la visión del otro e incluso en la planificación (o no) de las ciudades. Para Armando Silva, estas son siempre "ciudades imaginadas" porque no sólo se edifican materialmente, sino también con "objetos mucho más etéreos"; un sinnúmero de imágenes y mensajes que impregnan las representaciones ciudadanas (21). Pero la ciudad intangible tiene efectos bien tangibles, ya que "caracteriza y pre-define el mismo uso de la otra ciudad física", pues los imaginarios se objetivizan, "se en-carnan o se in-corporan" para expresar "sentimientos sociales" (Silva 22). Resalto en Silva: el carácter social de los imaginarios, que "corresponden a una imagen que hacen los ciudadanos de la ciudad"; y su poder transformador, el hecho de que "son susceptibles de operar en lo real para generar cambios en las conductas ciudadanas en ambientes públicos" (29). ${ }^{5}$

5 Pongo por ejemplo el imaginario social más reciente de Valparaíso como una ciudad de lo irracional, de lo creativo y artístico, de lo libidinal; que se conciba, por así decir, como una ciudad "para ser pintada", 
Las reflexiones de Guerra y Silva se hacen especialmente pertinentes para considerar la propuesta de Salvador Reyes en la evolución novelística nacional,6 me refiero al llamado imaginismo, ${ }^{7}$ que en controversia con el criollismo anterior impulsó desde 1928 una renovación estética basada en "una nueva perspectiva literaria, un enfoque más poético, fantástico y original, que le [dio] lugar al ensueño y a la imaginación" (Cit. en Ramírez 107). Teniendo en cuenta esta inscripción debe subrayarse la operación estética efectuada por el novelista: la de seleccionar un imaginario marítimo proveniente de las literaturas europeas para luego adaptarlo a la espacialidad y los imaginarios propios de los puertos chilenos. De este modo, se enfrentó no sólo al criollismo canonizado de Mariano Latorre en la célebre querella entre imaginistas y criollistas, sino también a la tradicional representación del puerto de Valparaíso, otorgándole "la dimensión marítima que le correspondía" (Ramírez 107), como, asimismo, podría agregarse, una nueva proyección urbana, al mirar con otros ojos el cosmopolitismo del Plan y el laberíntico trazado de los cerros. Todo esto dio un nuevo aire a la dialéctica entre la literatura porteña y los imaginarios sociales y, según ha observado Adolfo de Nordenflycht, dio alternativas a "la declinación del imaginario provisto por el proyecto de progreso y modernidad de los aventureros burgueses" (61). En una crónica de 1930, anterior a la escritura de sus dos grandes novelas porteñas - Valparaíso, puerto de nostalgia y Mónica Sanders-, Salvador Reyes ya había acusado los efectos indeseables de

y de hecho esto se concreta material y económicamente en los grafitis callejeros y en el colorido de las casas que atraen el turismo.

6 Como para Lucía Guerra, para Silva los imaginarios suponen un cruce entre y lo individual y lo colectivo en la percepción personal de una multiplicidad de "experiencias de mediación" que configuran la mirada social: "las mitologías, la literatura, el arte, las ciencias, las tecnologías o los medios, todas ellas fuentes engranadas por la historia y por las historias locales de cada comunidad y de los grupos que las forman" (Silva 41). Referido esto en particular al arte novelístico como fuente de imaginarios, agregaría yo que es, al mismo tiempo, un receptáculo de imaginarios, es decir, una suerte de válvula que recibe, transforma y devuelve imágenes nuevas a partir de lo anterior: las imágenes sociales y culturales, así como la historia personal, se encarnan y transforman en la obra literaria.

7 Dado que parece obvio vincular este imaginismo con la vanguardia literaria europea y su reivindicación del sueño y la imaginación como ámbitos más propios de la creatividad —además de su exaltación de la imagen como recurso literario-, hay que aclarar con Muñoz y Oelker que "los términos imaginista e Imaginismo comenzaron a emplearse, con evidente propósito peyorativo, durante la polémica entre criollistas e imaginistas, en 1928. El primero en llamar imaginistas a los escritores de esta tendencia fue Manuel Vega, quien los denomina 'puramente imaginativos' o 'imaginistas puros', para diferenciarlos de 'los grandes imaginistas de la literatura universal"' (129). Y que, siguiendo con los mismos autores, "obviamente estos 'grandes imaginistas' ni tampoco los 'imaginistas puros' de que habla Manuel Vega tienen relación con los 'imaginistas' ('imagists'), grupo de poetas ingleses y norteamericanos (Ezra Pound, Hilda Doolittle, Richard Aldington, D.H. Lawrence) que hacia 1914 formaron el movimiento literario denominado 'imaginismo' ('imagism')" (129). 
ese imaginario en la sociabilidad porteña: "En ninguna parte de Chile los jóvenes hablan de negocios con entusiasmo tan grande como aquí" (Cit. en Ramírez 120).

Pero Mónica Sanders no postula sólo una sencilla oposición a la sociedad burguesa, a la razón instrumental y a la industria cada vez más mecanizada y deshumanizante. A Salvador Reyes le ha tocado ver cómo el desmejoramiento económico al declinar la actividad portuaria barre también con la vibrante atmósfera cosmopolita, con la renovación constante del ambiente propiciada por gentes y productos extranjeros. Es por esto que, a mi modo de ver, la propuesta imaginaria de la novela frente a la decadencia del Valparaíso posterior al Crac de 1929, apoya su trama narrativa - compensatoriamente- en la pujante industria ballenera de Quintay. Esta surgió cuando la Compañía Indus, especializada en productos de limpieza, diversificó en 1936 sus actividades hacia el negocio ballenero y contrató, dada su tradición nacional, al ingeniero noruego Alf Larsen Rasmussen con el fin de levantar una planta faenadora en la caleta, cuya construcción se inició en 1941 para comenzar a operar en 1943 y alcanzar su época gloriosa durante la primera mitad de los años cincuenta (Küpfer-Lastarria 77-84). La industria ballenera impulsó una inmigración considerable de noruegos ejercitados en esa actividad a lo largo de los años cuarenta, justamente la década anterior a la publicación de la novela de Reyes.

A despecho de los informes celebratorios de El Mercurio de la época (Küpfer-Lastarria 83-84), en Mónica Sanders el repunte industrial y económico aparece bajo una mirada ambivalente: se admira la cultura marítima y la bohemia, la vida nocturna de las watts, así como el remozado aire cosmopolita. Pero se acusa también la alienación humana y la devastación ecológica que vienen incluidas. Esto último se canaliza especialmente, como se verá, en las lúgubres reflexiones del cronista burgués de ascendencia británica — y transposición biográfica de Reyesembarcado en el ballenero Alcatraz junto al capitán Julio Moreno, ${ }^{8}$ Percy Roy quien escribirá un reportaje sobre la cacería de los cetáceos. ${ }^{9}$ La mirada ambivalente de

8 Entre otros, Reyes dedica la novela al capitán Sufus Haugen y "a todos los tripulantes del INDUS 6, en agradecimiento de su cordial hospitalidad" (7). Se trata de "el célebre capitán Sofus Konrad Haugen, uno de los mejores arponeros de la flota" (Küpfer y Lastarria 112).

9 La fragilidad y escepticismo de Percy Roy lo recortan como una figura indeseable al trasluz del capitán Moreno, en parte transposición de un yo deseable, en tanto ejemplo de vigor y voluntad varonil. Como Borges — su colega en el Índice de la nueva poesía americana (1926)—, Reyes muestra una cierta "nostalgia del destino épico" (Borges, "Epílogo" 114) en la figura del capitán, mientras al mismo tiempo denosta en la figura del cronista la que fue su propia ocupación, la literatura, como también lo hiciera Borges al hablar de "las simétricas porfías del arte, / que entreteje naderías" (Borges, "El remordimiento" 455). El gesto es similar: el Borges viejo lo tematiza de manera más explícita e incluso patética; pero habla de la común 
la novela recurre a un imaginario social de la época descrito por el antropólogo Daniel Quiroz: mientras en el mar la cacería se representa como un heroico despliegue de fuerza, aventurero y vital, el procesamiento en tierra de la ballena se representa como una actividad prosaica y monótona (Cit. en Küpfer-Lastarria 87).

Consecuentemente, la novela exalta el espacio marítimo circundante de Valparaíso, que permite a quienes se adentran al mar escapar de la opresión citadina: "Bastaba un viaje como aquel, de tres o cuatro días, para que el rutinario personaje urbano cortara todos los lazos que lo unían a su ciudad" (72). El acto intelectual —cálculo de las condiciones: distancia, clima, etc.— y físico —arponeo y arrastre- de la cacería adquiere incluso implicancias metafísicas: a la par que realza el carácter y la individualidad, posibilita una comunión fraterna entre los hombres de mar cuya coordinación es de la mayor importancia para el éxito de la empresa. En contraste paradójico — puesto que la caza abastece a la industria_, la planta beneficiadora del Cerezo (Quintay) aparece como el más descarnado espacio del capital, donde la instrumentalización de la naturaleza y de los seres humanos, la acumulación por la acumulación que señala David Harvey, cobra las características de una pesadilla. Ahí, gracias a la higiénica modernización, "el visitante de estómago más delicado podía recorrer la fábrica de la Compañía Ballenera del Norte sin exponerse a sufrir la menor molestia” (Reyes 48). Pero bajo el shock que le provoca asistir al procesamiento mecanizado del animal, el cronista Percy Roy sufre una especie de alucinación en que el usufructo masivo y tecnificado de los recursos naturales - y es posible ver además una crítica a la modernolatría de ciertas vanguardias influyentes en la época juvenil de Reyes-, no es sino expresión racionalizada del más primitivo e irracional afán destructivo:

Por un instante el Gringo Roy tuvo la visión de una escena absurda en que la humanidad enloquecida aullaba y alzaba los brazos saludando su victoria sobre las fuerzas supremas de la naturaleza . . . ¡Victoria del hombre! ¡Ya no hay más bestias en las tierras ni en los mares! ¡Máquinas, sólo máquinas! (Reyes 102).

En tercer término, aparece en Mónica Sanders el espacio urbano de Valparaíso como lugar donde se contiene y resuelve la tensión entre el espacio alienado en la planta beneficiadora del Cerezo (Quintay), y el espacio de acción y liberación marítima frente a las costas de ese poblado y hasta la ciudad-puerto donde se despliega

filiación vanguardista de ambos escritores, que conservan el viejo anhelo de unir arte y vida, literatura y acción. La paradoja es que deben renunciar a esta última para efectuar la conjunción en el orbe simbólico, donde de todos modos queda marcada la huella nostálgica. 
la cacería de ballenas. Percy Roy, el descendiente inglés, que sin trabajar depende de la herencia paterna, mitifica las conexiones internacionales de la ciudad trazadas en gran parte por la comunidad británica durante el siglo XIX: "Valparaíso aparecía ligado a todos los puertos del mundo por un lazo sideral de estrellas y fanales. Era un eslabón del collar de fuegos que rodea el Planeta" (Reyes 70). Mientras que el capitán y arponero Julio Moreno, de clase media, visualiza las conexiones británicas internas de la urbe:

En la calle Blanco, como en Serrano, Prat, Lord Cochrane y otras del puerto, no escaseaban los rincones que sugerían alguna rápida imagen londinense ... La colonia británica, tan abundante en otro tiempo, había impreso su huella en las calles porteñas y en algunos cerros, como el Alegre y Playa Ancha (Reyes 42).

El personaje realiza en su interioridad emotiva, un mapeo de Valparaíso como espacio del capital, en tanto circuito financiero-mercantil, y deja fuera lo más crudo de su "secreto obsceno": los cerros poblados masivamente por el proceso gentrificador a fines del siglo XIX, y que luego, por efecto del Crac de la bolsa, padecieron oleadas de miseria extrema. De esta situación son elocuentes algunos hechos bien documentados, como el llamado "desfile del hambre" que en 1932 reunió a cinco mil personas (Estrada 125), y la masiva expulsión de indigentes transportados en tren hacia Chillán durante 1933 (Estrada 132-133).

En los relatos intercalados de la novela, como los protagonizados por el indigno contramaestre Bernardino Rubio, ambientados en otros cerros que el cerro Alegre y el casco antiguo de Playa Ancha (avenida Gran Bretaña) o en sectores del Plan ligados tradicionalmente a sujetos populares como la plaza Echaurren, se representa a los personajes bajo un imaginario delictual e indecente, 10 bajo un imaginario cómico, ${ }^{11}$ o bien bajo un imaginario "social" simplificado, mediante consignas afectadas. ${ }^{12}$ Salvo por el destacado monólogo interior de Bernardino, quien mirando la ciudad desde un mirador de la avenida Alemania, reflexiona con emocionada melancolía sobre su situación precaria, en una especia de amor fati

10 "Fueron donde unas niñas de la calle Clave, bebieron toda la noche, quebraron las poncheras y los vasos, y al alba, cuando salieron del prostíbulo, se batieron con un grupo de pijes” (Reyes 111).

11 "Bernardino, completamente borracho, quiso defenderse; pero el cocinero le cogió por un brazo y empezó a hacerlo girar rápidamente, dándole, a cada vuelta, una patada en el trasero” (Reyes 250).

12 Se habla, por ejemplo, de "la pobreza de hombres alertos a quienes el puerto nutre de reciedumbre y de inquietud; la pobreza de mujeres bravas para el trabajo . . . la pobreza que lucha por arrancarle a la vida los bienes que ésta le debe” (245). 
justificado sólo por el alcohol. ${ }^{13}$ Pero en general estos personajes de las clases más bajas no aparecen mayormente perfilados y la novela pone los valores del honor y el trabajo de parte de la clase media, entendida esta más como un conjunto de valores heredados — higiene, rectitud moral, ahorro, modales, frugalidad, etc.— que como un estatus económico, siempre más variable y accidentado.

Valparaíso mismo en el imaginario de la novela, no es otra cosa, entonces, que el tiempo perdido del capital británico; para ser más justos: el embrujo de Valparaíso no es otra cosa que la buella estructurante de ese tiempo perdido, visible aún —en el presente enunciativo de la novela - sobre el trazado urbano y la arquitectura de ciertos sectores de la ciudad, y admirado ahora en su valor de uso y de goce, y no ya en su mero valor de cambio, como posición estratégica para el flujo del capital entre Europa y la costa del Pacífico. Es pues, en el corazón de ese recorte urbano —el de la huella británica en Valparaíso-, donde Mónica Sanders, su esposo Percy Roy, su amante Julio Moreno y el capitán finlandés Gustavson se pierden en la noche para "conocer los misterios del puerto" (Reyes 158). Y es que en la novela la urbe porteña también exalta lo "humano-primordial", pero en la medida en que la ciudad es una suerte de proyección marítima, espejo de la caótica naturaleza del mar. El caos urbano de los cerros encarna una cierta autenticidad perdida, opuesta al trazado racional del Plan de Valparaíso, aunque lo hace de una forma menos agresiva que el mar, según dice el narrador de la novela: "Una tarde de primavera en ciertos cerros de Valparaíso es como un gato que viene a acurrucarse sobre nuestro pecho y a comunicar a nuestro viejo corazón su calor animal" (énfasis mío, Reyes 108).

Viña del Mar, por último, en su origen ciudad "de agrado" de la comunidad británica, espacio del capitalismo suntuario, y luego con la decadencia de Valparaíso, residencia definitiva, se representa en la novela bajo un imaginario tradicional de goce y elegancia, ya visible, por ejemplo, en la novela En el viejo Almendral (1943) de Joaquín Edwards Bello. Los encuentros eróticos clandestinos entre Julio Moreno y Mónica Sanders se producen en la trastienda de una modista amiga de Mónica, en una especie de parisina garconnière de la que modernamente dispone en este caso la mujer: "la salita, con un gran diván-lecho, un tocador y un gran espejo, era confortable..." (Reyes 182).

13 "El ex piloto se hallaba en paz con el destino, pero no podríamos atribuir este fenómeno a la sola influencia de la tarde: un litro de tinto había contribuido eficazmente a su beatitud" (109). 


\section{Imaginarios y comunidad: hacerse salvajes}

Al comenzar la última salida del barco ballenero, los tripulantes manifiestan alivio de encontrarse nuevamente en el mar. El mar (masculinizado) aparece a ojos del capitán Julio Moreno como una figura en clara oposición a la mujer (Mónica Sanders) y a la ciudad (Valparaíso), pero que logra integrar el opuesto femenino en la ballena, pues en el mar "[v]íctimas y victimarios se confundían en una misma fatalidad de acción en los claroscuros del drama sin fin, en las misteriosas líneas entrecruzadas de la vida y de la muerte" (Reyes 257). Con una mirada llena de amor hacia sus hombres, el capitán piensa que su autoridad se la ha ganado "a costa de hombría" y que, sin embargo, ahí, sobre el barco ballenero, lejos de convencionales escalafones, todos "se confundían con él en una estrecha solidaridad humana" (Reyes 259). Incluso cuando el pusilánime cronista Percy Roy avista a la ballena, el narrador, focalizado en su interioridad, dice que " $[\mathrm{u}] \mathrm{n}$ obscuro instinto se había despertado en él”, y añade que toda la tripulación experimenta una "alegre violencia" y "no forma más que un solo cuerpo" (Reyes 84).

Se sugiere pues, el regreso a una supuesta comunidad orgánica en la actividad conjunta de los tripulantes del ballenero Alcatraz capitaneado por Julio Moreno; el regreso a esa Gemeinschaft que para Ferdinand Tönnies, uno de los iniciadores a finales del siglo XIX del debate entre comunidad (tradicional) y sociedad (moderna), está cohesionada por la sangre, por el lugar o por el espíritu, es decir: por parentesco, por vecindad o por el trabajo cooperativo hacia una meta conjunta (Tönnies 100). Esta comunidad tradicional o Gemeinschaft arrastrará tópicamente en la teoría todo un imaginario de lo íntimo y hogareño. Pero el mar, lo salvaje, al mismo tiempo que en la novela conduce a una vida más auténtica — despertando un impulso primigenio dormido bajo la urbanidad-, conlleva el peligro de una cierta disolución dionisíaca o incluso de una pulsión de muerte. Este aspecto de la comunidad lo subraya Roberto Esposito al repensar con un instrumental filosófico fraguado en las problemáticas éticas y políticas posmodernas, el viejo debate planteado por Tönnies: "Hay que tener siempre presente esta doble cara de la communitas: es al mismo tiempo la más adecuada, si no la única, dimensión del animal 'hombre', pero también su deriva, que potencialmente lo conduce a la disolución" (Espósito 33). La libertad individual, pues, queda en riesgo y es parte del precio a pagar por la comunidad, al menos si, como parece ser el anhelo del capitán Julio Moreno, se aspira a retornar a la intimidad hogareña de la Gemeinschaft cohesionada por una sola voluntad surgida entre individuos de historias idénticas en agrupaciones cerradas a la influencia extraña, según la idealización de Tönnies. 
Incluso con este peligro la comunidad del mar parece, a ojos de la novela, más deseable que la sociedad de la planta beneficiadora del Cerezo. Ahí, los obreros no corren, por supuesto, el riego de la disolución, pero tampoco - y por lo mismoel beneficio de realizar una acción conjunta que despliegue sus individualidades. De ambos extremos los resguarda el hecho de que se encuentran despersonalizados por la mecanicidad — por el tiempo homogéneo y vacío- de su labor al descuartizar los cetáceos: "un enjambre de pequeños hombrecillos se afanaban [sic] en arrancarles trozos de carne más grandes que ellos mismos" (105). Estos "hombrecillos" hacen notorio contraste con las figuras cuasi homéricas de los hombres del mar. Asimismo, la ballena queda ahí despojada de su calidad de enemigo épico para convertirse en mero producto industrial. Hasta la prosa a menudo poética de Reyes adquiere en estos pasajes un deslavado registro técnico: "La ballena era aprovechada íntegramente según procedimientos propios de la compañía. El aceite, los huesos, la carne, la esperma, todo tenía su aplicación” (104-105). Siguiendo con Ferdinand Tönnies, no habría aquí otra cosa que la comunidad contractual o Gesellschaft, "compuesta por convención y derecho natural, [y que] ha de entenderse como una multitud de individuos naturales y artificiales, cuya voluntades y esferas mantienen muchas relaciones entre sí, quedando sin embargo independientes y libre de las relaciones familiares mutuas" (Tönnies 152), y vinculada en la teoría a un imaginario de fría transacción mercantil individualista, a la prosa del mundo. Sin desmedro de su actividad coordinada, los destazadores de ballenas están lejos de inmiscuirse entre sí y formar una "estrecha solidaridad humana" (Reyes 259), como en el barco ballenero, al estar cohesionados exclusivamente por el interés común del salario.

No es en la planta beneficiadora del Cerezo (Quintay), ni en el ballenero Alcatraz (mar adentro), ni en la trastienda viñamarina del erotismo, ni en la bohemia porteña donde se hace posible la comunidad cuya búsqueda llena de angustia al capitán y arponero. "El embrujo", "el misterio" de Valparaíso es sólo una presencia fantasmática - y por eso insuficiente — de ese capitalismo británico de antaño, más acogedor y más humano en el sentir nostálgico que envuelve a la novela. El entorno urbano de Valparaíso, espacio y comunidad fantasmal, sólo tiene para Julio Moreno la virtud de otorgarle una libertad, por un lado, a resguardo de la disolución fraternal en la comunidad del mar y, por otro lado, a resguardo de la decadente comodidad burguesa que comienza a representar la relación con Mónica Sanders. Resguardo provisional, en la medida en que el "laberinto" de la ciudad va a identificarse, a cuadrarse cada vez más con esta relación.

Siguiendo la tradición antiburguesa de la vanguardia histórica, la novela buscará una alternativa huyendo hacia lo primitivo y lo salvaje. Julio Moreno acepta enton- 
ces capitanear un barco ballenero que se adentrará en la Antártica, recurriendo la sintaxis novelística y su trasunto ideológico a un imaginario instalado por la lectura de cierta vanguardia respecto del simbolismo y de Nietzsche. Para esta la única salida, dicho en versos de Baudelaire, a ese "oasis de horror en un desierto de tedio" (227) que había probado ser la sociedad burguesa, estaría en sus extramuros: en lo "bárbaro", en las culturas periféricas, en lo desconocido de la muerte; sólo allí estaría "lo nuevo" (Baudelaire, "El viaje" 229). La baudeleriana invitación, la llamada a buscar en otra parte la vida auténtica, es explícita cuando el gerente general de la Compañía Ballenera Antártica celebra a Julio Moreno por su decisión de embarcarse: “Usted necesita el mar, su barco, su arpón. ¡Esa es su verdadera vida!” (Reyes 263). De ahí la identificación entre una comunidad auténtica y la huida hacia el frío polar, fuera de la civilización. Incluyéndose en el mito griego del pueblo hiper-bóreo, dice Nietzsche en las primeras líneas de El anticristo (1895): "Mirémonos a la cara. Nosotros somos hiperbóreos, — sabemos muy bien cuán aparte vivimos. 'Ni por tierra ni por agua encontrarás el camino que conduce a los hiperbóreos'; ya Píndaro supo esto de nosotros. Más allá del norte, del hielo, de la muerte — nuestra vida, nuestra felicidad..." (31). Salvo que, por razones de verosimilitud, en Mónica Sanders se trata del hielo sur y no del Polo norte donde el mito griego localiza lo totalmente-otro-deseable.

Atendiendo a la pulsión de muerte manifiesta en la cita del filósofo y en todo ese imaginario con que se afilia la novela, podría interpretarse que es a la negación de toda comunidad a lo que aspira el arponero Julio Moreno en su viaje final. El hacerse salvajes del simbolismo-vanguardismo, surgido de la figura del buen salvaje, dice Mario de Micheli, "[d]e mito convergente sobre la realidad social para modificarla, se transforma en mito divergente de tal realidad para reencontrar, fuera de ella, fuera de su brutalidad, una felicidad no contaminada e inocente" (50). Mitificado además por las biografías de Rimbaud y Gauguin, entre otros, el hacerse salvajes representa tras el desencanto parisino con la Comuna de 1878, según de Micheli, "una fuga individual, una solución individual, pues ya no hay “ideas generales" (49). Significativamente, uno de los libros posteriores de Salvador Reyes, tras finalizar Mónica Sanders con la gélida huida de Julio Moreno, se titulará El continente de los hombres solos (1956), que el autor escribió luego de un viaje a la Antártica reafirmando en su obra el eslabonamiento metafórico viaje-frío-soledad-masculinidad-muerte.

De la recurrencia a este imaginario es que se desprende una interpretación (literaria, implícita) como la de Roberto Bolaño, quien acusa a Reyes de un misticismo evasivo de dudosa filiación ideológica. ${ }^{14}$ Desde el concepto de comunidad, en el

14 En Nocturno de Chile (2000) se produce un encuentro, al parecer ficticio, entre el novelista chileno y 
marco del debate más actual sobre la Gemeinschaft (comunidad tradicional) y la Gesellschaft (sociedad moderna) quisiera hacer por mi parte una lectura opuesta. Para el filósofo Jean-Luc Nancy la comunidad fundada en la comunión íntima y acabada es un mito retrospectivo de la sociedad moderna ${ }^{15} \mathrm{y}$, de hecho, "las empresas políticas o colectivas dominadas por la voluntad de inmanencia absoluta tienen por verdad la verdad de la muerte" (34). Nancy está pensando en la Alemania nazi, en los "comunismos reales" e incluso en el tópico literario del suicidio de los amantes (34). A mi modo de ver, la huida del capitán Julio Moreno representaría justamente el alejamiento de este tipo de comunidad que aspira a la "intimidad comulgante", a la "inmanencia absoluta" (Nancy 34) y cuyo destino es la gradual exclusión de toda alteridad y, por lo tanto, la autodestrucción: por un lado, el modelo épico-masculino del ballenero Alcatraz, por otro lado, el modelo de la fusión romántica — según él la ve y no ella — en la relación con Mónica Sanders: "Te quedas por el momento [dice ella cuando el capitán miente con renunciar a su viaje a la Antártica]; pero yo me encargo de que sea para siempre" (Reyes 240). La paradoja de la huida final de Julio Moreno encarna una de las paradojas de la comunidad auténtica; asumir como su horizonte la soledad de la muerte propia: "Una comunidad es la presentación a sus miembros de su verdad mortal" (Nancy 39); y que esta comunidad no puede relevar la muerte según prometen los totalitarismos: "no opera la transfiguración de sus muertos en la sustancia o en el sujeto que sea - patria, tierra o sangre natal, nación, humanidad emancipada o realizada, falansterio absoluto, familia o cuerpo místico" (Nancy 38). En su alejamiento del sueño suicida de la Gemeinschaft al hacerse salvaje, hecho posible justamente en y por la comunidad, Julio Moreno va muy por otro lado de la evasión y — en cuanto transposición de Salvador Reyessigue la vía de esos vanguardistas para quienes el exotismo surgía de una "repulsión activa” (Micheli 60). Así, el imaginario de la comunión en la muerte, la disolución dionisiaca — resignificada por la vanguardia futurista - y la fusión amorosa, no parecen formularse como alternativa de comunidad en Mónica Sanders.

Ernst Jünger, que en su Tempestades de acero (1920) exalta heroicamente la muerte en las trincheras, al estilo de los futuristas italianos. En plena Segunda Guerra Mundial, en una embajada parisina, Reyes es conducido "a través de varios salones, cada salón se abría a otro salón, como rosas místicas, y en el último salón había un grupo de oficiales de la Wehrmacht y varios civiles y el centro de atención de toda esta gente era el capitán Jünger, el héroe de la Primera Guerra Mundial” (38). Resulta evidente la alusión irónica al imaginario místico del nazismo.

15 "El pensamiento o el deseo de la comunidad podría entonces, perfectamente, ser no más que el invento tardío que intentó responder a la dura realidad de la experiencia moderna [...] De modo que la comunidad, lejos de ser lo que la sociedad habría roto o perdido, es lo que nos ocurre — pregunta, espera, acontecimiento, imperativo- a partir de la sociedad" (Nancy 32-33). 
Es preciso reconocer, sin embargo, que el viaje del capitán hacia el territorio Antártico se hace posible sólo gracias a la expansión del capital; al decir de David Harvey y Marx, sólo gracias a su necesidad de "aniquilar el espacio por el tiempo" (Harvey 262). Porque, por lejano y frío, por despoblado que aparezca a nuestra imaginación, ese espacio Antártico representado es ya, al estar incorporado al extractivismo, un "espacio dominado, esto es, pasivamente experimentado" (Lefebvre 97). En este caso, se trata de un espacio dominado por, y vivido al interior del entramado del capital industrial de la Compañía Ballenera Antártica, que ha comprado los barcos y planea con ese viaje abrir una planta procesadora en la isla Decepción, a la entrada del territorio Antártico nacional, donde se aglomera la materia prima de las ballenas. Pero el hacerse hiperbóreo —ir más allá de todo código que restrinja la "nuda" experiencia- del capitán, no sólo resulta socavado por esta paradoja, sino por una cierta ironía donde por fin se hace relevante el personaje femenino. Julio Moreno planea sin advertencias ni explicaciones el abandono de su amante, Mónica Sanders, lo que ella termina sabiendo antes de tiempo y acepta en silencio, sin reproches. El capitán, burlador burlado, se enfurece al enterarse de esto — en ausencia de ella — la misma tarde de su partida, y así reproduce a nivel simbólico la violencia patriarcal que surge, según explica Rita Segato, al momento en que la mujer, excediendo los márgenes del "nicho restricto" que le traza el dominio del hombre - nicho cuyo mantenimiento le asegura a este último su permanencia en "el mundo de la masculinidad"-, da muestras de poseer "un resto que no cabe enteramente en su papel en el orden de estatus, un algo más, una agencia libre, un deseo otro que no es el de la sumisión" (145). ${ }^{16}$ En su elocuente silencio final, Mónica Sanders altera con un aire de cotidiana modernidad el imaginario de la femme fatale que ostenta en un comienzo. ${ }^{17} \mathrm{El}$ tenor trágico del hacerse salvaje

16 Don Ante, entendiendo la arbitrariedad de su ego masculino, le dice: "Te creías haberla engañado y te embarcabas muy satisfecho. ¡Y ahora vienes con estas cojudeces!... ¡Ten cuidado de que no sea esa mujer la que te diga las cuatro frescas! ¡Déjate de tonterías, Julio! ¡Pórtate como un hombre y no como un chiquillo!" (Reyes 289).

17 Erika Bornay detecta el itinerario de la femme fatale desde el decadentismo finisecular hasta la primera mitad del siglo XX, y dice que "de Esfinge hierática, o de perfumada y exótica Salomé, la mujer pasará, en un breve espacio de tiempo, a anunciar las excelencias de un determinado chocolate, cigarrillos o a decorar la cabecera de la lista del menú de cualquier restaurante" (382). Pero a partir de los años veinte la imagen se ve revitalizada con la aparición del cine, y emerge un desfile de "misteriosas princesas árabes y seductoras reinas egipcias de voraz sexualidad y peligrosa cabellera. .." (398). A mi juicio, la figura de Mónica Sanders recupera un imaginario más bien publicitario, extrayendo algo de la fogosidad sexual de la mujer fatal actualizada por el cine, pero de manera secundaria. Mónica Sanders es, sobre todo, la mujer moderna, norteamericana, de posguerra, que con elegancia y desenvoltura sociabiliza entre los hombres mientras fuma y bebe whisky: "Moreno observaba la delicadeza de los dedos que sostenían el vaso o el movimiento de los labios al recibir el cigarrillo" (Reyes 148). 
del capitán Moreno resulta ironizado por el personaje femenino que ahora vemos que le da título a la novela no sólo a nombre de objeto de deseo, sino también de sujeto deseante y agente. El hecho de habitar donde se habita con total determinación - ella celebra la ciudad reiteradamente y jamás siente el hastío del capitán-, sin tener en vistas la "invitación al viaje" o una "verdadera vida" en otro lugar (idealizado), sugiere Mónica Sanders, otorga la vitalidad (real) de lidiar con -y encontrar una alternativa a - los dilemas del presente; en el caso de Valparaíso, al dilema entre la nostalgia por la comunidad británica (esa Gemeinschaft) y el enuui por la sociedad (Gesellschaft) en su estado actual de decadencia.

\section{Comunidad y espacio: isla Decepción}

En Mónica Sanders el espacio marítimo concebido, planificado, como flujo de mercancías y personas, además de como fuente de explotación de materias primas, y percibido como espacio de relaciones productivas por parte de los hombres de mar, es, sin embargo, al mismo tiempo, vivido por ellos como espacio de aventura, de expansión interior y comunidad. Aunque se trata de una comunidad eminentemente masculina y amenazada de forma constante por la oscura potencia disolutiva del mar, tan sublime como destructor. ${ }^{18}$ El matrimonio y la vida citadina no ofrecen tampoco una alternativa, mucho menos los márgenes con los que coquetea el capitán: la relación ilícita con Mónica Sanders en Viña del Mar y sus escarceos matonescos fuera del Plan de Valparaíso, en los sectores más alejados y pobres de la ciudad. La verdadera vida, que no es otra cosa que la hogareña comunidad donde se nos da seguridad y libertad a partes iguales, en realidad no está en ninguna parte, o lo está en cualquier lugar muy lejos, y por eso mismo Julio Moreno siempre está buscándola y jamás la encuentra, de tal modo preserva intacto su deseo.

18 En dos de las portadas más conocidas de la novela, la iconografía hace referencia a mensajes paradigmáticos de la dominación masculina que, al decir de Bourdieu, se sostiene sobre una visión androcéntrica, desde donde las diferencias biológicas de los cuerpos se instituyen en "fundamentos objetivos de la diferencia entre los sexos, en el sentido de géneros construidos como dos esencias sociales jerarquizadas" (36-37). En la edición de Zig-Zag de 1951 aparece la imagen del capitán Moreno en primer plano y de frente, y solo en segundo plano y mucho más pequeña asoma Mónica Sanders sobre su hombro izquierdo, mostrando tres cuartos de perfil con sonrisa sugerente. No es necesario escarbar mucho en el archivo de refranes patriarcales para hallar justificada esa posición secundaria: "detrás de todo gran hombre hay una gran mujer", se diría; el imaginario bíblico también resuena en la imagen: la mujer surge desde el lado izquierdo del hombre; la mujer susurra al oído invitando a morder la manzana y pecar, etc. En la edición de Andrés Bello de 1983, es Mónica Sanders quien toma el primer plano de la portada, ya no con faz lujuriosa sino melancólica; sobre su hombro y a lo lejos aparece un barco adentrándose en el mar, haciendo clara referencia al dicho popular, poetizado por Neruda, según el cual: "En cada puerto una mujer espera, / los marineros besan y se van" (43). 
Para Zygmunt Bauman, que piensa el concepto de comunidad desde la perspectiva sociológica, “[e]l privilegio de 'estar en comunidad' tiene un precio: y sólo es inofensivo, incluso invisible, en tanto que la comunidad siga siendo un sueño" (11). Mantener la comunidad como sueño, evitar su prosaica y dolorosa concreción, es lo que el personaje pretende, pues así escapa al hecho de que "[p]erder la comunidad significa perder la seguridad; ganar comunidad, si es que se gana, pronto significaría perder la libertad" (Bauman 11). Por eso abandona Valparaíso (pierde seguridad y gana libertad) y se apresta a viajar a la Antártica (donde perderá libertad y ganará seguridad): en ese momento intermedio no se tiene ni seguridad ni libertad, pero es la forma en que la novela pretende ganar, por así decir — y esta es su poética-, una forma de sublime liberación en la experiencia pura. Pero los hielos, como ya se ha dicho, portan un imaginario demasiado denso como para resultar una neutral tierra de ensueño, colonizado en el imaginario europeo — desde la mitología griega hasta las mitologías nacionalsocialistas- por enormes superhombres vencedores de la muerte.

Lo de Julio Moreno es, si cabe decirlo, una utopía eternamente diferida, la resistencia a cerrar o concretar la utopía, de darle lugar, el mantenimiento a distancia del objeto de deseo porque la posesión — la realidad — tiende a degradarlo, pero esto supone, pienso, la íntima esperanza de que en otro plano exista un perfecto acoplamiento entre deseo y posesión (la inmanencia absoluta); en definitiva, el personaje opta por no escoger la comunidad real por el hecho de que no existe o no se da nunca la comunidad ideal; se aleja de la comunidad imperfecta en la fantasía de alcanzar algo que es constitutivamente inasible, pues "[l]a comunidad . . asume la imposibilidad de su propia inmanencia, la imposibilidad de un ser comunitario en cuanto sujeto. La comunidad asume e inscribe — es su gesto y su trazado propios-, de alguna manera, la imposibilidad de la comunidad" (Nancy 38).

Mientras el capitán Julio Moreno realiza este rodeo frente a la necesidad de establecer un equilibrio entre libertad y seguridad en una comunidad real, Mónica Sanders elige la confrontación y se toma con humor y sin dramatismos la indecisión primero y luego el engaño del capitán, quien le promete quedarse en Valparaíso habiendo firmado ya su contrato en la Compañía Ballenera Antártica. Como es lícito imaginar tras el fin de la novela, ella continúa el pacto abierto, sin hipocresías, con su marido, donde ambos — hasta donde alcanzamos a ver- logran equilibrar la seguridad y la libertad; la seguridad de un matrimonio hogareño y la libertad de mantener amantes por fuera. Por supuesto con sus sacrificios y privilegios, como se aprecia en la novela, pues "ambas [seguridad y libertad] igualmente acuciantes e indispensables, son difícilmente reconciliables sin fricciones" (Bauman 13). Pero esta fricción es el rasgo fundamental de la comunidad cuando la hay. 


\section{Conclusión: la comunidad que existe}

Por último, poniendo en contraste la comunidad de Julio Moreno y la comunidad de Mónica Sanders, vale decir lo siguiente. Una cosa es la comunidad como mito retrospectivo, esa comunidad fundada en el entendimiento "natural" y no en el consenso social; y otra es la comunidad que ya se tiene o se pretende fundar tras una ardua negociación entre posiciones diferentes; y que aspira a un arraigo más cálido que el mero vínculo contractual de la sociedad o Gesellschaft (Bauman 3-4) y menos impracticable que el ensueño de una Gemeinschaft premoderna. Julio Moreno rehúye la comunidad "realmente existente" (Bauman 11); la del ballenero Alcatraz, la del amor de Mónica Sanders, la del Valparaíso de lejanos aires ingleses en la amistad con el matrimonio Sanders-Percy, porque la seguridad de estas, como la de cualquier comunidad real, pone en riesgo su libertad: por esto prefiere la búsqueda —es decir, el encuentro siempre diferido— de la comunidad ideal.

Pero si la seguridad de la comunidad existente puede resultar opresiva, la libertad fuera de esta, en el mero ensueño, se hace muy pronto vertiginosa e inhabitable, y por esta razón la búsqueda de Julio Moreno tiene un lugar predeterminado; nuevamente, aunque esta vez en la Antártica, al interior de la comunidad de los hombres de mar cohesionada, al mismo tiempo, por un heroísmo primordial y por el interés extractivo de una compañía ballenera. ${ }^{19}$ Mientras para el capitán la libertad es provisoria fuera del laberinto del capital —el breve momento de su huida de Valparaíso para instalarse en "el continente de los hombres solos", citando el elocuente título del libro posterior de Reyes_- para Mónica Sanders se hace posible en las fisuras urbanas y sociales del cada vez más ruinoso Valparaíso de los años treinta. En la casona que habita en Playa Ancha "la tapia se encontraba derruida en un espacio de tres o cuatro metros y . . ., a juzgar por las huellas, los habitantes de la quinta entraban y salían por esa abertura" (Reyes 129). Mucha de su seguridad y libertad se debe, por cierto, al ascendiente británico y de alta burguesía que funda al matrimonio Roy-Sanders y, por lo tanto, se trata de una comunidad de difícil proyección dada la decadencia - metaforizada en la tapia derruida - de ese grupo. En definitiva,

19 En la empresa naviera se aprecia la tendencia del capitalismo moderno, según Bauman, de sustituir el entendimiento natural de la antigua comunidad y, consecuentemente, el de resucitar un sentimiento comunitario en el nuevo estado de cosas (28); como ejemplo pone los altos sueldos de la empresa Ford y las aldeas modelo propuestas por filántropos en la misma época (27-29). Esto no resulta difícil, por otra parte, al capitalizar una práctica ligada a tradiciones culturales premodernas como la cultura marítima y la caza de ballenas. El barco recrea a su modo los lazos y el entorno físico de la comunidad en el espacio del capital producido por la industria ballenera. Los sociólogos industriales descubrieron pronto, al comenzar el siglo XX, que más barato y productivo que los sueldos altos, y pongo énfasis en la metáfora, es causar "el sentimiento de que 'todos estamos en el mismo barco"" (Bauman 30). 
la novela, captada en su totalidad, se debate en una irresolución entre la seguridad ya impracticable del vibrante pasado cosmopolita y la difusa perspectiva del futuro cooptado por el espacio del capital industrial y tecnificado en la isla Decepción o, mejor dicho, en Deception Island (isla Engaño) como es su nombre original. Con amargura aristocratizante, la novela parece aceptar finalmente que la naturaleza de la comunidad "realmente existente" (Bauman 11) es el mantenimiento de un equilibrio precario, en permanente y difícil negociación entre la libertad y la seguridad, y que su obtención ideal es imposible y peligroso su deseo.

A Salvador Reyes, como queda dicho, le ha tocado ver cómo el desmejoramiento económico de Valparaíso en tanto espacio del capital, al declinar la actividad portuaria, barre también con la vibrante atmósfera cosmopolita de finales del siglo XIX. Es por esto que la propuesta imaginaria de la novela frente a la decadencia del Valparaíso posterior al Crac de 1929, apoya su trama en la industria ballenera de Quintay. El repunte industrial y económico aparece, sin embargo, bajo una mirada ambivalente: se admira la cultura marítima y la bohemia, el viril despliegue de fuerzas en la cacería de las ballenas. Pero el procesamiento fabril de los cetáceos en tierra se representa como una actividad prosaica que aliena a los destazadores y devasta la naturaleza. Esto parece obstruir la nostalgia por el ambiente cosmopolita de la burguesía británica decimonónica, y resulta cada vez más difícil recuperar los antiguos aires londinenses, que permanecen en destellos fugaces o epifanías y hacen el "hechizo" de Valparaíso. De este, por lo demás, quedan excluidos los sectores y sujetos que ya están al margen del capital, y se los representa bajo imaginarios delictuales, indecentes, cómicos o paternalistas.

De todos modos, frente al imaginario social de ese "hechizo" del Valparaíso hegemónico se impone la decadencia encarnada por Mónica Sanders y su esposo Percy Roy, descendientes ingleses cínicos y vividores, "femeninos", que no parecen estar a la altura de la nostalgia encarnada por los "viriles" hombres mar, como Julio Moreno. Estos hacen honor al pasado decimonónico enfrentando las fuerzas sublimes de la naturaleza, cuyo pálido reflejo urbano es el caos citadino de los cerros mirados desde el Plan, huella lejana de lo viril-primordial. Al tiempo que el mar propone al protagonista, Julio Moreno, una vida más auténtica, le presenta el peligro de una cierta disolución dionisíaca o pulsión de muerte; así como la relación con Mónica Sanders representa para él los peligros de la disolución erótica o el riesgo de la hipocresía y comodidad burguesas. Por esto buscará, en un imaginario propio de las vanguardias históricas, "hacerse salvaje" y huir hacia soledad del territorio antártico. Dos lecturas se abren al respecto: o bien el personaje se aleja de la "intimidad comulgante" o "inmanencia absoluta" (Nancy 34) en algún tipo de esencia (eso ve en la fraternidad y en el amor); o simplemente se repliega 
en sí mismo fuera de toda comunidad y, por lo tanto, no hay en su búsqueda un reconocimiento del límite común a lo humano —única condición de la comunidad no esencialista—, sino una cabal pulsión de muerte. Cualquiera de las dos, la burla final de Mónica Sanders, ironiza cómicamente el tenor trágico-masculino de la búsqueda del capitán, ${ }^{20}$ oponiendo frente al "nicho restricto" (Segato 145) de objeto secundario, sumiso y deseado en que, en tanto mujer, la ubica la comunidad masculina, su dimensión de sujeto deseante y agente (ella que, a fin de cuentas, da título a la novela): no resulta una mujer abandonada, sino una mujer que elige confrontar el presente en una comunidad decadente pero concreta en el espacio urbano de Valparaíso, y lejos de la motivación nostálgica del capitán; se libera así del imaginario estereotipado de la femme fatale que la envuelve al comienzo y asume el protagonismo de la novela.

20 Confluye aquí el "vuelco" femenino de la novela con su talante ecológico. Joseph W. Meeker propone una dicotomía entre lo trágico (heroico, idealista, conquistador) y lo cómico (en armonía con el entorno, terrenal, no agrede, sale del paso). En la tradición occidental se ha privilegiado la primera conducta humana cuyo fruto es morir y destruir por ideas, tender a lo metafísico en desmedro de la tierra. En momentos de crisis ecológica se hace necesario revalidar el aspecto cómico, conservador en sentido de la supervivencia (Cit. en Binns 175-176). 


\section{Obras citadas}

Alone. "Mónica Sanders". Alone y los premios nacionales de literatura. Santiago: Dirección de Bibliotecas y Archivos de Museo, 1992.

Baudelaire, Charles. "El viaje". Las flores del mal. Barcelona: Penguin, 2017.

Bauman, Zygmunt. Comunidad. En busca de seguridad en un mundo hostil. Madrid: Siglo XXI, 2003.

Binns, Niall. Nicanor Parra o el arte de la demolición. Valparaíso: Editorial UV, 2014.

Bolaño, Roberto. Nocturno de Chile. Barcelona: Anagrama, 2000.

Borges, Jorge Luis. Poesía completa. Barcelona: Debolsillo, 2013.

Bornay, Erika. Las hijas de Lilith. Madrid: Cátedra, 1996.

Bourdieu, Pierre. La dominación masculina. Barcelona: Anagrama, 2000.

Candia, Alexis y Óscar Rosales. "Pleamar del deseo en la narrativa de Salvador Reyes". Atenea 515 (2017): 63-80.

Candia, Alexis, Oscar Rosales y Patricio Landaeta. "Porteñas buenas mozas: corazón y belleza en la construcción de la mujer en la narrativa de Salvador Reyes". Alpha 43 (2016): 157-173.

Goic, Cedomil. Brevisima relación de la historia de la novela hispanoamericana. Madrid: Biblioteca Nueva, 2009.

Guerra-Cunningham, Lucía. Ciudad, género e imaginarios urbanos en la narrativa latinoamericana. Santiago: Cuarto propio, 2014.

Harvey, David. "La geografía de la acumulación capitalista: reconstrucción de la teoría marxiana”. Espacios del capital. Hacia una geografía crítica. Madrid: Akal, 2007.

Küpfer, Marcela y Carlos Lastarria. La ballenera de Quintay y otros relatos de la caza de ballenas en Chile. Valparaíso: Narrativa Punto Aparte, 2017.

Lefebvre, Henri. La producción del espacio. Madrid: Capitán Swing Libros, 2013.

Micheli, Mario de. "Hacerse salvajes". Las vanguardias artísticas del siglo XX. Madrid: Alianza, 2017. 
Montecinos, Manuel. "Salvador Reyes, el gran marinista". La Segunda, 27/01/94: 6-7. Memoria Chilena: http://www.memoriachilena.cl/602/w3-article-70185. $\underline{\mathrm{html}}$

Muñoz, Eduardo "Efectos de la crisis de 1929 en los sectores populares de Valparaíso: una visión desde el diario La Unión”. Valparaíso: progresos y conflictos de una ciudad puerto (1830-1950). Comp. Baldomero Estrada Turra. Santiago: RIL Editores, 2012.

Muñoz, Luis y Dieter Oelker. Diccionario de movimientos y grupos literarios chilenos. Concepción: Ediciones Universidad de Concepción, 1993.

Nancy, Jean-Luc. La comunidad inoperante. Trad. Juan Manuel Garrido Wainer. Santiago: LOM/ARCIS, 2000.

Neruda, Pablo. “Farewell”. Crepusculario. Santiago: Nascimiento, 1926.

Nietzsche, Friedrich. El Anticristo. Maldición sobre el cristianismo. Madrid: Alianza, 2002.

Nordenflycht, Adolfo de. "Valparaíso como espacio de la aventura en el imaginario de la narrativa imaginista". Atenea 504 (2011): 55-72.

Oyarzún, Luis. “Prólogo”. Mónica Sanders. Santiago: Zig-Zag, 1966.

Ramírez, Ana. "Valparaíso en la perspectiva literaria del imaginismo". Valparaíso. Visión multidisciplinaria II. Valparaíso: Academia Superior de Ciencias Pedagógicas de Valparaíso, 1981.

Reyes, Salvador. “¿Existe el embrujo de Valparaíso?”. Crónicas. Santiago: Ediciones Portada, 1974. . Mónica Sanders. Santiago: Zig-Zag, 1951.

Segato, Rita. Las estructuras elementales de la violencia. Ensayos sobre género entre la antropología, el psicoanálisis y los derechos bumanos. Buenos Aires: Universidad Nacional de Quilmes, 2003.

Silva, Armando. Imaginarios, el asombro social. Bogotá: Universidad Externado de Colombia, 2013.

Solar, Hernán del. “Salvador Reyes: Mónica Sanders”. El Mercurio, 14/09/75.

Tönnies, Ferdinand. Comunidad y asociación. El comunismo y el socialismo como formas de vida social. Madrid, Biblioteca Nueva, 2011 